\title{
EVALUATING SURVIVAL OF GREATER SAGE-GROUSE CHICKS IN STRAWBERRY VALLEY, UTAH, BY USE OF MICROTRANSMITTERS: DOES HANDLING TIME NEGATIVELY INFLUENCE SURVIVAL RATES?
}

\author{
Jared J. Baxter ${ }^{1,5}$, Jordan P. Hennefer ${ }^{2}$, Rick J. Baxter ${ }^{1}$, Randy T. Larsen ${ }^{1,3}$, and Jerran T. Flinders ${ }^{4}$
}

\begin{abstract}
Research indicates that low nest success and juvenile survival may be factors contributing to Greater Sage-Grouse population declines. Recent technological advances in microtransmitters have allowed researchers to monitor individual chicks and broods. We initiated a chick survival study in 2006 and used microtransmitters to (1) examine the viability of using microtransmitters on chicks to assess survival, including the effect of handling time during the suturing process; (2) estimate overall chick survival; and (3) compare chick survival in the Strawberry Valley population to other published reports. We used a known-fate model in program MARK to estimate $\hat{c}$ (overdispersion), weekly survival rates, and 49-day survival of radio-marked chicks. Chick survival rates were lowest during the initial 3 weeks of life, after which point weekly survival stabilized. Survival over 49 days was estimated at 0.25 (SE 0.10 ) and was comparable to estimates from other populations. Handling time was negatively associated with chick survival, and chicks were 2 times more likely to survive to 49 days when handled for only 5 minutes instead of 19 minutes. We recommend that researchers be judicious in using microtransmitters and make every effort to reduce handling time during transmitter attachment.
\end{abstract}

RESUMEN.-Las investigaciones indican que el bajo éxito de anidación y la supervivencia juvenil del gallo de salvia pueden ser factores que contribuyen a la disminución de las poblaciones. Los recientes avances tecnológicos en microtransmisores permiten a los investigadores monitorear individualmente a los polluelos y a las nidadas. Iniciamos un estudio de supervivencia de polluelos en el año 2006 utilizando microtransmisores con el fin de (1) examinar si se pueden utilizar microtransmisores en polluelos para evaluar la supervivencia, incluyendo el efecto del tiempo de manipulación durante el proceso de sutura; (2) estimar la supervivencia general de los polluelos; y (3) comparar la supervivencia de los polluelos en la población de Strawberry Valley contra informes ya publicados. Utilizamos un modelo de destino conocido en el programa MARK para estimar c c (sobredispersión), los índices de supervivencia semanal y la supervivencia de 49 días de los polluelos marcados. Los índices más bajos de supervivencia de los polluelos fueron durante las primeras tres semanas de vida, en este punto, el índice de supervivencia semanal se estabilizó. La supervivencia de los 49 días se estimó en 0.25 (SE 0.10) y fue comparable con las estimaciones de otras poblaciones. El tiempo de manipulación se asoció de manera negativa con la supervivencia de los polluelos, los cuales tuvieron el doble de probabilidades de sobrevivir a los 49 días cuando se los manipuló durante sólo 5 minutos, en lugar de 19 minutos. Recomendamos a los investigadores que sean cautos al tomar la decisión de utilizar microtransmisores, y que, si lo hacen, intenten reducir el tiempo de manipulación.

Populations of Greater Sage-Grouse (Centrocercus urophasianus) have experienced declines up to $47 \%$ across their range (Connelly and Braun 1997, Garton et al. 2011). Although this decline could be a function of quality and contiguity of habitat (Drut et al. 1994, Connelly et al. 2000, Aldridge and Boyce 2007, Gregg et al. 2007) exacerbated by periodic drought (Braun 1998) and excessive or unnecessary prescribed burning, herbicide application, and mechanical treatments (Crawford et al. 2004), low recruitment rates may also be a contributing factor (Aldridge and Brigham 2001, Aldridge 2005, Beck et al. 2006).
Methods used to estimate survival of sagegrouse chicks and the time period of interest for generating estimates have changed with advancements in technology. June (1963) used brood surveys and counts to estimate chick survival to early fall. Schroeder (1997) and Aldridge and Brigham (2001) estimated chick survival to 50 days by flushing radio-marked hens with broods and counting the number of chicks. More recently, biologists have estimated chick survival using microtransmitters and radiotelemetry. Burkepile et al. (2002), Aldridge (2005), and Gregg et al. (2007) attached radio-transmitters to chicks and estimated chick

\footnotetext{
${ }^{1}$ Department of Plant and Wildlife Sciences, Brigham Young University, 275 WIDB, Provo, UT 84602-5253.

${ }^{2}$ Rangeland Management Specialist, 1405 Hollipark Drive, Idaho Falls, ID 83401.

3 Assistant Curator of Birds, Monte L. Bean Life Science Museum, Provo, UT 84602-5253.

${ }^{4}$ Emeritus Professor, Brigham Young University, 17082 Snake River Rd., Asotin, WA 99402.

${ }^{5}$ E-mail: baxter.jaredj@gmail.com
} 
survival to 21,56 , and 28 days, respectively. Beck et al. (2006) emphasized the lack of consistency among chick survival studies and classified chicks as $0-10$ weeks of age. Finally, Dahlgren et al. (2010) determined that brood surveys may not accurately depict survival rates when brood mixing is known to occur and reported an overall chick survival rate to 42 days.

Preliminary information from research in Strawberry Valley, Utah, suggested that, as with other grouse populations, chick survival might limit population growth (Baxter 2003) and could partially explain the $>97 \%$ reduction in the Strawberry Valley sage-grouse population observed over the last 70 years (Griner 1939, Bunnell 2000). Given this decline in Greater Sage-Grouse abundance and its potential association with chick survival, we estimated chick survival rates directly using microtransmitters and radiotelemetry. Our objectives were to (1) examine demographic and research-induced factors potentially affecting chick survival, including handling time, chick mass, and hen age; (2) estimate overall chick survival to 49 days; and (3) compare chick survival in the Strawberry Valley population to other published studies.

\section{METHODS}

\section{Study Area}

The Strawberry Valley study area measures $\sim 24,200$ ha and is located in Wasatch County, Utah, south of the Uinta and east of the Wasatch mountain ranges (UTM 12T, $490900 \mathrm{E}, 4446500$ $\mathrm{N})$. The valley is characterized as montane sagebrush steppe with elevations ranging from 2280 to $2440 \mathrm{~m}$. Mountain big sagebrush (Artemisia tridentata vaseyana) is the dominant shrub found in the area, with silver sagebrush (Artemisia cana) occurring in wet meadows and riparian corridors. Strawberry Reservoir was originally completed in 1922 but was later expanded in 1985; it is the most dominant feature in the valley, consisting of up to 6950 surface hectares of water ( $\sim 29 \%$ of the study area) that has decreased and fragmented the sagebrush habitat. The climate is characterized by cool summers $\left(13.5^{\circ} \mathrm{C}\right)$ and cold, wet winters $\left(-8.7^{\circ} \mathrm{C}\right)$, with mean annual precipitation of $58 \mathrm{~cm}$.

\section{Data Collection}

We captured Greater Sage-Grouse hens in 2005-2006 from March to May by using a modified spotlight method (Wakkinen et al.
1992). Ages of hens were determined on the basis of feather characteristics (adult or yearling; Crunden 1963, Bihrle 1993), and each hen received a 22-g necklace radio-transmitter (Advanced Telemetry Systems, Inc., Isanti, $\mathrm{MN}$ ). Mean hen mass was $1373 \mathrm{~g}$; therefore, on average, this transmitter represented $1.6 \%$ of their weight. Some hens captured in 2005 produced nests and chicks in 2006.

In 2006, we located radio-marked hens from the ground at nest sites by using a 4-element Yagi antenna and an R-1000 digital radio receiver (Communication Specialists Incorporated, Orange, CA). Following identification of nests, we projected a hatch date using the last date the hen was not observed on a nest and the subsequent date it was located on a nest (without flushing it). We then monitored each hen 2-3 times each week at a distance of $\geq 10 \mathrm{~m}$ until eggs hatched. In the last $4-5$ days of incubation, we visited the nest site every other day.

After the eggs hatched, we located the hen and captured, by hand, as many chicks as possible. We captured most chicks in the morning, although a few were caught later in the day. We placed captured chicks in a cotton bag, where they could move freely until a radio-transmitter was affixed. We recorded the approximate age in days ( \pm 1 day) of each chick based on the time between capture and the last known date the hen was on a nest. We measured body mass by using a Micro-line spring scale (Forestry Suppliers Inc., Jackson, MS) and recorded the location of the capture site in Universal Transverse Mercator (UTM) coordinates by using a handheld GPS unit. We then sutured a 1.6-g transmitter (ATS Model A4320; $\leq 72$ days of battery life) on each chick (2\%-6\% of body weight) following the methods of Burkepile et al. (2002).

To facilitate transmitter attachment, we restrained chicks with a Styrofoam board modified with a hole (= chick restraining board). We placed the legs of the chick through the hole and secured the feet on the underside. We used a rubber band placed around the legs of the chick and ensured that the band was tight enough to secure the chick but loose enough to allow it to struggle without injury and to maintain normal circulation. We then restrained the head of each chick using a strip of Velcro attached to the board.

Following attachment of the transmitter and visual assessment of the condition of each 
TABLE 1. List of a priori models used to assess survival to 49 days of Greater Sage-Grouse chicks in Strawberry Valley, Utah, USA, 2006.

\begin{tabular}{|c|c|}
\hline Model structure & Hyposthesis description \\
\hline$\{\mathrm{S}(7$-week $\mathrm{T}+\mathrm{HT})\}$ & Survival varied in a 7-week linear trend with handling time \\
\hline$\{\mathrm{S}(\mathrm{TT})\}$ & Survival varied in a 3 -week quadratic trend \\
\hline$\{\mathrm{S}(\mathrm{TT}+\mathrm{HT})\}$ & Survival varied in a 3 -week quadratic trend with handling time \\
\hline$\{\mathrm{S}(7$-week TT $)\}$ & Survival varied in a 7 -week quadratic trend \\
\hline$\{\mathrm{S}(7$-week $\mathrm{T})\}$ & Survival varied in a 7 -week linear trend \\
\hline$\{\mathrm{S}(7$-week TT $+\mathrm{HT})\}$ & Survival varied in a 7 -week quadratic trend with handling time \\
\hline$\{\mathrm{S}(\mathrm{T})\}$ & Survival varied in a linear trend \\
\hline$\{\mathrm{S}(\mathrm{TT}+\mathrm{HenAge})\}$ & Survival varied in a 3-week quadratic trend with hen age \\
\hline$\{\mathrm{S}(7$-week $\mathrm{T}+\mathrm{HenAge})\}$ & Survival varied in a 7 -week linear trend with hen age \\
\hline$\{\mathrm{S}(7$-week $\mathrm{T}+\mathrm{HT}+$ ChickMass $)\}$ & $\begin{array}{l}\text { Survival varied in a } 7 \text {-week linear trend with handling time and } \\
\text { chick mass }\end{array}$ \\
\hline$\{\mathrm{S}(\mathrm{TT}+\mathrm{HT}+\mathrm{HenAge})\}$ & $\begin{array}{l}\text { Survival varied in a } 3 \text {-week quadratic trend with handling time and } \\
\text { hen age }\end{array}$ \\
\hline$\{\mathrm{S}(\mathrm{TT}+\mathrm{HT}+$ ChickMass $)\}$ & $\begin{array}{l}\text { Survival varied in a } 3 \text {-week quadratic trend with handling time and } \\
\text { chick mass }\end{array}$ \\
\hline$\{\mathrm{S}(\mathrm{TT}+$ ChickMass $)\}$ & Survival varied in a 3-week quadratic trend with chick mass \\
\hline$\{\mathrm{S}(7$-week TT + ChickMass $)\}$ & Survival varied in a 7-week quadratic trend with chick mass \\
\hline$\{\mathrm{S}(7$-week $\mathrm{T}+$ ChickMass $)\}$ & Survival varied in a linear trend for the first 3 weeks \\
\hline$\{\mathrm{S}($ first 3 weeks $)\}$ & Survival varied in a linear trend for the first 3 weeks \\
\hline$\{\mathrm{S}(\mathrm{HT})\}$ & Survival varied with handling time \\
\hline$\{\mathrm{S}(\mathrm{TT}+\mathrm{HT}+$ HenAge + ChickMass $)\}$ & $\begin{array}{l}\text { Survival varied in a 3-week quadratic trend with handling time, hen } \\
\text { age, and chick mass }\end{array}$ \\
\hline
\end{tabular}

chick for injury or stress, we released the chicks individually into sagebrush cover at the point of capture. Thus, handling times varied for each chick within a brood. Generally, the hen was in the vicinity of the capture area making noises that would likely gather her brood. After releasing all chicks, we immediately left the area. Throughout this process, we monitored the amount of time the chick was in the cotton bag, as well as the time required to weigh each chick, attach a transmitter, and release it into sagebrush cover (handling time). The results helped us to determine the efficacy of the chick restraining board and assess the influence of handling time on survival rates. Following release, we monitored each chick once every 2 days until we found it dead, until its radio-transmitter signal was lost, or until it survived to 49 days post-hatch (termed 'recruitment').

\section{Statistical Analysis}

To evaluate chick survival, we used model selection (Burnham and Anderson 2002) and the known-fate model in program MARK (White and Burnham 1999). We first created an encounter history for each radio-marked chick by dividing our proposed recruitment period of 49 days into 7 one-week intervals from capture to mortality or recruitment. We assumed that all factors we included in the analysis that may have influenced survival were different for each chick in each time interval. Because fates of chicks in the same brood were likely not independent, we used an ad hoc approach to calculate $\hat{\mathrm{c}}$ and correct for overdispersion. To estimate $\hat{c}$, we followed methods outlined by Bishop et al. (2008) and used the average value of $\hat{c}$ calculated from estimates of overdispersion obtained from 10,000 simulations of each of the models with a time-dependent effect $(\mathrm{t})$.

We formulated 18 a priori models to explain variation in survival rates (Table 1). Each model represented survival as a function of a combination of time effects and individual covariates. For individual covariates, we evaluated the influence of chick handling time, chick mass, and hen age. We chose handling time as a covariate because of our hypothesis that increased handling times may stress chicks to the point where survival could be affected. We chose chick mass as a covariate because of our hypothesis that mass directly affects fitness and survivability. In addition, we chose hen age as a covariate based on our hypothesis that older hens may be more experienced in hiding offspring, luring away predators, and so forth, consequently leading to higher chick survival.

Because many galliformes show low survival during the initial weeks of life (Patterson 1952, Holloran 1999, Hannon and Martin 


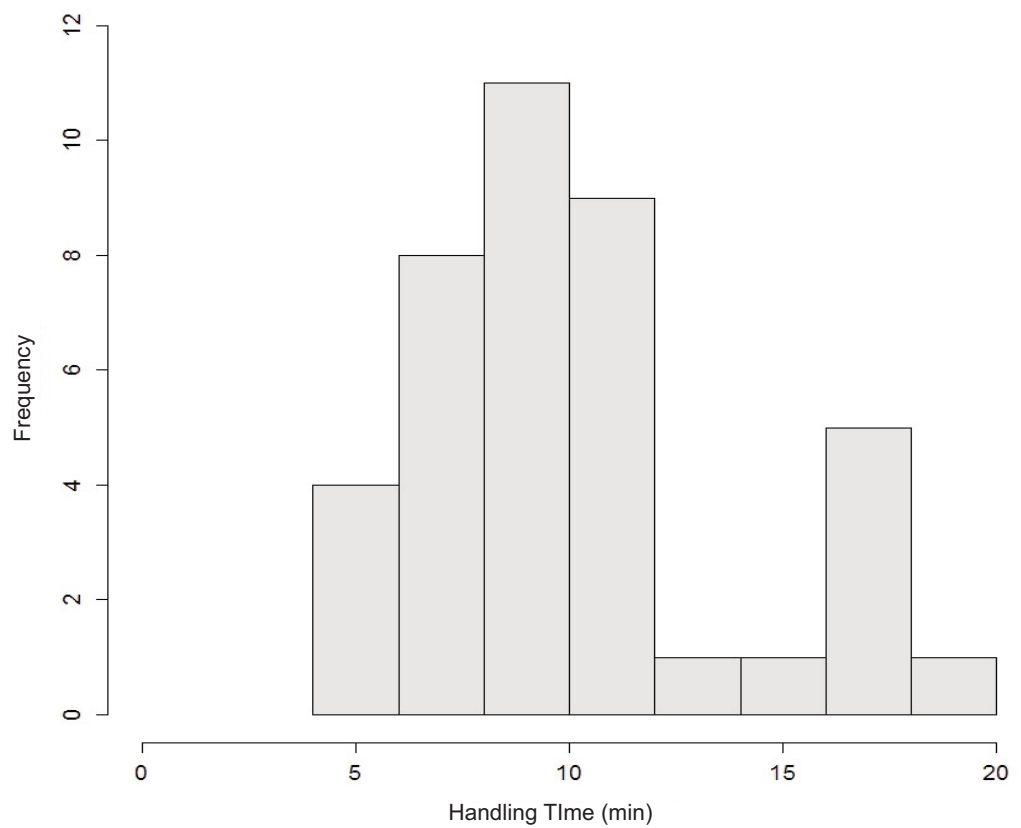

Fig. 1. Frequency of handling times for Greater Sage-Grouse chicks in Strawberry Valley, Utah, USA, 2006.

2006), we also used trend (T) and quadratic trend (TT) models in combination with our covariates to explain survival rates. We assessed support for both 3- and 7-week trends (Table 1). We ranked models using the quasiAkaike's information criterion adjusted for small sample size $\left(\mathrm{QAIC}_{c}\right.$; Burnham and Anderson 2002). When model selection uncertainty occurred, we used model averaging to produce estimates of real (weekly) and derived (49-day) survival parameters. Values are presented as means with standard errors.

\section{RESUlTS}

We attached transmitters to 40 Greater Sage-Grouse chicks captured from 19 broods in 2006. We captured 1 chick each from 8 unique broods; 2 chicks each from 5 unique broods; 3 chicks each from 2 unique broods; and 4 chicks each from 4 unique broods. No more than 4 chicks were captured per brood. All captured chicks were $\leq 7$ days old $(\bar{x}=2$ days) and had a mean body mass of $36 \mathrm{~g}$. Mean handling time per chick was 10.7 minutes (SE 3.7, range 5-19 minutes; Fig. 1). No chicks died or were injured at any point from capture through release. Apparent survival of chicks to 49 days was $25 \%$ (10 of 40$)$. Five (26\%) of the
19 broods had at least one chick survive to 49 days post-hatch.

The average value of $\hat{c}$ was 2.342 , indicating a relatively large amount of interdependence between broodmates. After use of this value to correct for overdispersion, 2 of the top 3 ranked models included the covariate chick handling time. The 2 most parsimonious models contained almost identical weight. One of those models included a 7-week linear trend with the covariate chick handling time $\left(w_{i}=0.098\right.$; Table 2$)$. The second model was simply a 3-week quadratic trend $\left(w_{i}=0.097\right)$. The next most supported model contained a 3 -week quadratic trend with the covariate handling time $\left(w_{i}=0.093\right)$. For models that had $\geq 1 \%$ of the $\mathrm{QAIC}_{c}$ weight and the individual covariate for handling time, $\beta$ estimates of handling time ranged between -0.19 and -0.16 . With the $\mathrm{QAIC}_{c}$ correction, the confidence intervals for each of these estimates ranged from -0.38 on the low end to 0.05 on the high end and overlapped zero in each case.

The derived estimate for probability of survival to 49 days when handling time was 5 minutes was 0.34 (SE 0.18; Fig. 2). This estimate was more than double the derived estimate of survival to 49 days when handling time was 19 minutes (0.16, SE 0.14). When using 


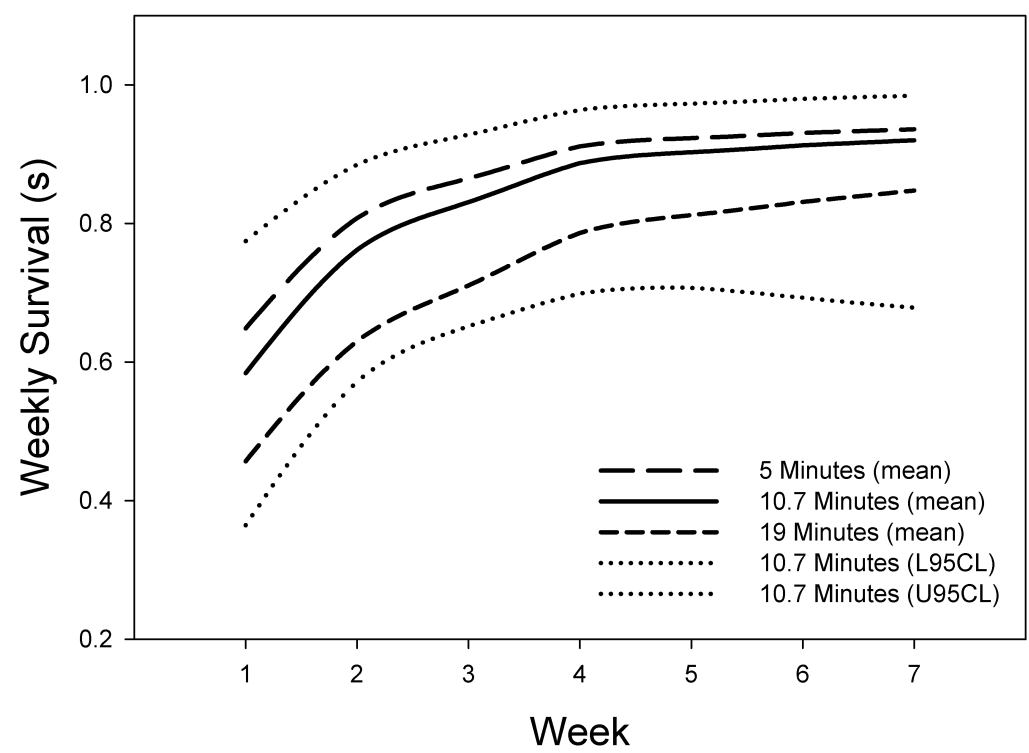

Fig. 2. Model-averaged survival estimates for Greater Sage-Grouse chicks in Strawberry Valley, Utah, USA, 2006, when handling time was 5, 10.7, and 19 minutes with 10.7-minute 95\% upper and lower confidence intervals.

TABLE 2. Model results ( $\geq 1 \%$ of model weight) for assessment of chick survival to 49 days for Greater Sage-Grouse in Strawberry Valley, Utah, USA, during 2006 showing quasi-Akaike's information criterion $\left(\mathrm{QAIC}_{c}\right), \Delta \mathrm{QAIC}_{c}$, model weight $\left(w_{i}\right)$, number of parameters $(K)$, and model deviance (QDeviance).

\begin{tabular}{|c|c|c|c|c|c|}
\hline Model & $\mathrm{QAIC}_{c}$ & $\Delta \mathrm{QAIC}_{c}$ & $w_{i}$ & $K$ & QDeviance \\
\hline$\{\mathrm{S}(7$-week $\mathrm{T}+\mathrm{HT})\}$ & 55.808 & 0.000 & 0.098 & 3 & 49.615 \\
\hline$\{\mathrm{S}(\mathrm{TT})\}$ & 55.813 & 0.005 & 0.097 & 2 & 51.717 \\
\hline$\{\mathrm{S}(\mathrm{TT}+\mathrm{HT})\}$ & 55.912 & 0.104 & 0.093 & 3 & 49.718 \\
\hline$\{\mathrm{S}(7$-week TT $)\}$ & 55.916 & 0.108 & 0.093 & 2 & 51.820 \\
\hline$\{\mathrm{S}(7$-week $\mathrm{T})\}$ & 55.924 & 0.116 & 0.092 & 2 & 51.828 \\
\hline$\{\mathrm{S}(7$-week TT $+\mathrm{HT})\}$ & 56.095 & 0.287 & 0.085 & 3 & 49.901 \\
\hline$\{\mathrm{S}(\mathrm{T})\}$ & 56.290 & 0.482 & 0.077 & 2 & 52.194 \\
\hline$\{\mathrm{S}(\mathrm{TT}+$ HenAge $)\}$ & 57.565 & 1.757 & 0.041 & 3 & 51.372 \\
\hline$\{\mathrm{S}(7$-week $\mathrm{T}+$ HenAge $)\}$ & 57.684 & 1.876 & 0.038 & 3 & 51.491 \\
\hline$\{\mathrm{S}(7$-week $\mathrm{T}+\mathrm{HT}+$ ChickMass $)\}$ & 57.713 & 1.905 & 0.038 & 4 & 49.388 \\
\hline$\{\mathrm{S}(\mathrm{TT}+\mathrm{HT}+$ HenAge $)\}$ & 57.717 & 1.909 & 0.038 & 4 & 49.392 \\
\hline$\{\mathrm{S}(\mathrm{TT}+\mathrm{HT}+$ ChickMass $)\}$ & 57.846 & 2.038 & 0.035 & 4 & 49.521 \\
\hline$\{\mathrm{S}(\mathrm{TT}+$ ChickMass $)\}$ & 58.905 & 2.097 & 0.034 & 3 & 51.711 \\
\hline$\{\mathrm{S}(7$-week TT +ChickMass $)\}$ & 58.011 & 2.203 & 0.032 & 3 & 51.818 \\
\hline$\{\mathrm{S}(7$-week $\mathrm{T}+$ ChickMass $)\}$ & 58.015 & 2.207 & 0.032 & 3 & 51.821 \\
\hline$\{\mathrm{S}($ first 3 weeks $)\}$ & 59.527 & 2.719 & 0.025 & 2 & 54.431 \\
\hline$\{\mathrm{S}(\mathrm{HT})\}$ & 59.267 & 3.459 & 0.017 & 2 & 55.171 \\
\hline$\{\mathrm{S}(\mathrm{TT}+\mathrm{HT}+$ HenAge + ChickMass $)\}$ & 59.662 & 3.854 & 0.014 & 5 & 49.171 \\
\hline
\end{tabular}

mean handling time of 10.7 minutes, we estimated survival to 49 days to be 0.25 (SE 0.10 ).

\section{Discussion}

Our results suggested that increased handling time could have a negative effect on chick survival rates. Handling time and capture myopathy-related mortalities have been reported in previous studies of Greater Sage-Grouse chicks. Burkepile et al. (2002) reported handling time as $<30$ minutes for 3 chicks and recorded no mortalities during the suturing process, although one mortality was surmised to be investigator related. Aldridge (2005) reported handling time as approximately 10 minutes per chick, as well as one capture myopathy-related mortality (out of 41 radio-marked chicks). Gregg et 
TABLE 3. A comparison of observed chick survival in Strawberry Valley, Utah, USA, during 2006 to survival periods and survival estimates reported in other studies.

\begin{tabular}{lcc}
\hline $\begin{array}{l}\text { Estimated survival } \\
\text { period }\end{array}$ & $\begin{array}{c}\text { \% Chick } \\
\text { survival } \\
\text { reported }\end{array}$ & $\begin{array}{c}\text { \% Survival in } \\
\text { Strawberry } \\
\text { Valley }\end{array}$ \\
\hline $\begin{array}{c}21 \text { days (Burkepile et al. } \\
\text { 2002) }\end{array}$ & 22 & 37 \\
28 days (Gregg et al. 2007) & 19 & 33 \\
28 days (Gregg and Craw- & 39 & 33 \\
$\quad \begin{array}{l}\text { ford 2009) } \\
42 \text { days (Dahlgren et al. }\end{array}$ & 50 & 27 \\
$\begin{array}{l}\text { 2010) } \\
49 \text { days (Estimated from } \\
\text { program MARK) }\end{array}$ & - & 25 \\
50 days (Schroder 1997) & 33 & 25 \\
56 days (Aldridge 2005) & 12 & - \\
\hline
\end{tabular}

al. (2007) reported handling time as $\leq 90 \mathrm{~min}-$ utes per brood in 2001 and $\leq 45$ minutes per brood in 2002, and 2 surgery-related mortalities (out of 288 captured chicks). In addition, they reported 11 mortalities at or near capture sites $<1$ day after capture. However, the possible effect of handling time on chick survival has not been examined previously. As a result, and due to the difficulty of comparing handling times between studies, we do not know and can make no inference regarding the effect of handling time on survival of chicks in those studies; handling time may or may not have affected chick survival rates. However, in our study, no chicks died during the handling process, nor did we observe any signs of stressrelated mortalities from the handling process. Nonetheless, handling time was present in many of the top models with $\beta$ estimates, suggesting it was negatively related to survival rates. Our results suggest that handling time may not cause immediate mortality due to the handling and suturing process, but it may affect overall chick survival rates indirectly. This indirect effect may occur due to increased human scent on the chick, increased chance of abandonment by the hen, or greater difficulty of the chick in finding the hen post-handling. Our limited sample size restricts our ability to more completely evaluate how handling time affected our chick survival rates.

Other investigators have suggested that use of transmitters on sage-grouse chicks did not affect survival rates (Burkepile et al. 2002, Aldridge 2005, Gregg et al. 2007, Dahlgren et al. 2010). We cannot rebut nor add support to this claim because we did not compare survival rates of marked and unmarked chicks. Our sample size $(n=40)$, collected during only one year, also limits our inferences. In addition, because we did not provide a heat source for chicks during the handling and suturing process, it is unknown what effect, if any, this may have had on chick survival rates in our study. However, survival rates of chicks in our study were comparable to those reported in other studies (Burkepile et al. 2002, Aldridge 2005, Gregg et al. 2007, Gregg and Crawford 2009; Table 3).

Our results support the use of time trends in models for chick survival. Our top 5 models each contained one time trend, including a 7week linear trend, a 7-week quadratic trend, or a 3-week quadratic trend, consistent with low survival during the early weeks of life (Fig. 2). These results are similar to others reported for Greater Sage-Grouse (Patterson 1952, Holloran 1999) and consistent with those commonly reported for other grouse species (Bergerud 1988, Hannon and Martin 2006).

Our results demonstrate little support for the covariates chick mass and hen age. Neither chick mass nor hen age appeared in any of the top 7 models. Of the covariates we tested, handling time had the greatest effect on chick survival. Therefore, we suggest that handling time be minimized to reduce its direct or indirect effect on chick survival.

Investigators should be cautious when estimating survival rates of radio-tagged chicks. If handling times are lengthened due to inexperience or inappropriate techniques, results may be biased. For that reason, we suggest that handling time be minimized to increase the probability of chick survival. Methods to reduce handling time include but are not limited to using more than one researcher in the handling process, procuring suturing experience on domestic galliformes prior to beginning research on wild birds, and utilization of a chick restraining board to decrease singleperson processing times. Our research suggests that reducing chick handling time will likely positively influence chick survival and allow researchers to use microtransmitters to obtain useful information on Greater SageGrouse chick survival, ecology, and life history.

\section{ACKNOWLEDGMENTS}

We thank the Utah Reclamation, Mitigation, and Conservation Commission, the Utah 
Division of Wildlife Resources, the USDA Forest Service, and Sportsmen for Fish and Wildlife for providing funding and support for this study. We also thank private landowners for their cooperation in allowing us access to their lands. Approval of all methods described herein was granted by the Institutional Animal Care and Use Committee at Brigham Young University (\#06-0402) and the Utah Division of Wildlife Resources (COR\# 1COLL6817).

\section{Literature Cited}

ALDRIDGE, C.L. 2005. Identifying habitats for persistence of Greater Sage-Grouse (Centrocercus urophasianus) in Alberta, Canada. Doctoral dissertation, University of Alberta, Edmonton, Alberta, Canada.

AldRIDGE, C.L., AND M.S. Boyce. 2007. Linking occurrence and fitness to persistence: habitat-based approach for endangered Greater Sage-Grouse. Ecological Applications 17:508-526.

Aldridge, C.L., AND R.M. Brigham. 2001. Nesting and reproductive activities of Greater Sage-Grouse in a declining northern fringe population. Condor 103: $537-543$.

BAXTER, R.J. 2003. Greater Sage-Grouse brood and nonreproductive female habitat selection and population dynamics in Strawberry Valley, Utah. Master's thesis, Brigham Young University, Provo, UT.

Beck, J.L., K.P. Reese, J.W. Connelly, and M.B. Lucia. 2006. Movements and survival of juvenile Greater Sage-Grouse in southeastern Idaho. Wildlife Society Bulletin 34:1070-1078.

Bergerud, A.T. 1988. Population ecology of North American grouse. Pages 578-685 in A.T. Bergerud and M.W. Gratson, editors, Adaptive strategies and population ecology of northern grouse. University of Minnesota Press, Minneapolis, MN.

BiHRle, C. 1993. Upland game identification: a basic guide for aging and sexing the bird in your hand. North Dakota Outdoors 56:9-23.

Bishop, C.J., G.C. White, AND P.M. Lukacs. 2008. Evaluating dependence among mule deer siblings in fetal and neonatal survival analyses. Journal of Wildlife Management 72:1085-1093.

Braun, C.E. 1998. Sage grouse declines in western North America: what are the problems? Proceedings of the Western Association of State Fish and Wildlife Agencies 78:139-156.

BunnelL, K.D. 2000. Ecological factors limiting sage grouse recovery and expansion in Strawberry Valley, Utah. Master's thesis, Brigham Young University, Provo, UT.

Burkepile, N.A., J.W. Connelly, D.W. Stanley, and K.P. REESE. 2002. Attachment of radio-transmitters to one-day-old Sage Grouse chicks. Wildlife Society Bulletin 30:93-96.

Burnham, K.P., And D.A. Anderson. 2002. Model selection and multi-model inference: a practical information-theoretic approach. 2nd edition. SpringerVerlag, New York, NY.

Connelly, J.W., and C.E. Braun. 1997. Long-term changes in sage grouse (Centrocercus urophasianus) in western North America. Wildlife Biology 3: $229-234$.

Connelly, J.W., M.A. Schroeder, A.R. Sands, and C.E. Braun. 2000. Guidelines to manage sage grouse populations and their habitats. Wildlife Society Bulletin 28:967-985.

Crawford, J.A., R.A. Olson, N.E. West, J.C. Mosley, M.A. Schroeder, T.D. Whitson, R.F. Miller, M.A. GregG, AND C.S. Boyd. 2004. Ecology and management of sage-grouse and sage-grouse habitat. Rangeland Ecology and Management 57:2-19.

Crunden, C.W. 1963. Age and sex of sage grouse from wings. Journal of Wildlife Management 27:846-850.

Dahlgren, D.K., T.A. Messmer, and D.N. Koons. 2010. Achieving better estimates of Greater Sage-Grouse chick survival in Utah. Journal of Wildlife Management 74:1286-1294.

Drut, M.S., W.H. Pyle, and J.A. Crawford. 1994. Diets and food selection of sage grouse chicks in Oregon. Journal of Range Management 47:90-93.

Garton, E.O., J.W. Connelly, C.A. Hagen, J.S. Horne, A. Moser, AND M.A. Schroeder. 2011. Greater SageGrouse population dynamics and probability of persistence. Pages 293-381 in S.T. Knick, J.W. Connelly, and C.E. Braun, editors, Greater Sage-Grouse: ecology and conservation of a landscape species and its habitats. Studies in Avian Biology, Number 38, University of California Press, Berkeley, CA.

GregG, M.A., AND J.A. Crawford. 2009. Survival of Greater Sage-Grouse chicks and broods in the northern Great Basin. Journal of Wildlife Management 73:904-913.

Gregg, M.A., M.R. Dunbar, and J.A. Crawford. 2007. Use of implanted radiotransmitters to estimate survival of Greater Sage-Grouse chicks. Journal of Wildlife Management 71:646-651.

Griner, G.L. 1939. A study of sage grouse (Centrocercus urophasianus), with special reference to life history, habitat requirements, and numbers of distribution. Master's thesis, Utah State Agricultural College, Logan, UT.

Hannon, S.J., and K. Martin. 2006. Ecology of juvenile grouse during the transition to adulthood. Journal of Zoology 269:422-433.

Holloran, M.J. 1999. Sage grouse seasonal habitat use near Casper, Wyoming. Master's thesis, University of Wyoming, Laramie, WY.

JunE, J.W. 1963. Wyoming sage grouse population measurement. Proceedings of the Western Association of State Game and Fish Commissioners 43:206-211.

Patterson, R.L. 1952. The sage grouse in Wyoming. Sage Books, Denver, CO.

Schroeder, M.A. 1997. Unusually high reproductive effort by sage-grouse in a fragmented habitat in northcentral Washington. Condor 99:933-941.

Wakkinen, W.L., K.P. Reese, J.W. Connelly, and R.A. Fisher. 1992. An improved spotlighting technique for capturing sage grouse. Wildlife Society Bulletin 20:425-426.

White, G.C., And K.P. Burnham. 1999. Program MARK: survival estimation from populations of marked animals. Bird Study 46 Supplement: 120-139.

Received 18 September 2012 Accepted 31 May 2013 